\title{
METHODS AND APPROACHES IN RISK MANAGEMENT - AN OVERVIEW OF POSSIBILITIES OF THEIR CATEGORIZATION
}

\author{
[Metody a přístupy v řízení rizik - přehled možností jejich členění] \\ Martina Žwaková ${ }^{1}$ \\ ${ }^{1} V \check{S} B$ - Technical University of Ostrava, Faculty of Economics, Sokolská třída 33, 70200 Ostrava \\ Email: martina.zwakova@vsb.cz
}

\begin{abstract}
As a result of constant changes in a business environment, companies are confronted with a significant number of risks. Such development is supposed to bring higher risk management requirements. Demands on systematic risk management framework creation are also newly included in revised ISO 9001:2016 standard. Under these conditions, companies should pay sufficient attention to risk management methods. The aim of the paper is to focus on risk management methods and their possible evaluation. Particular views on existing evaluation or classification of methods available from resources focused on the issue of the risk management methods are described and possibilities for further categorization of methods are outlined. In the paper an attempt to examine approaches to risk management and methods in a real business environment through a questioning. Due to a smaller number of respondents the questioning is used as a complementary to the overview of methods and approaches and to provide a starting point for a further research.
\end{abstract}

Keywords: approaches to risk management, classification, questionnaire survey, risk management methods.

JEL classification: M10, M19, M21, D80, C38

Doručeno redakci: 29.9.2017; Recenzováno: 28.1.2018; 8.2.2018; Schváleno k publikování: 14.3.2018

\section{Introduction}

Risks are integral parts of the world and are one of its characteristics (for example Smejkal and Rais (2013)), so it is impossible for subjects to completely avoid them. Although risks can vary in different business areas, there are threads affecting all companies or business units (systematic risks) (Tichý 2006), Fotr and Hnilica (2014). Under these conditions, specific procedures, techniques or a whole system should be used for risk treatment or decreasing a level of risk. Such framework termed generally risk management consists of a wide variety of steps and methods which can be used for identification, measurement and analysis or risks (Tichý 2006), (Smejkal and Rais 2013), (Chapman 2006), (Fotr et al. 2012). The aim of the paper is to focus on risk management methods and their possible evaluation.

Due to a big amount of methods that can be used, it is appropriate to categorize them according to various criteria. Many approaches to their classification are mentioned in the professional literature. Even a framework for classification is included in ISO 31010. This framework is based on more than one factor. In this paper, there is a focus on factors for evaluation of the risk management methods. The definition of the factors that could be used for evaluation is based on the literature review connected with risk management and its methods. When the framework for evaluation is set, the cluster analysis is considered to be appropriate to form or identify groups of methods. Elementary features of this procedure are outlined with the assumption that it will be verified in future from a view of the applicability for purpose of classification of methods and to be examined in further details.

Although there are wide varieties of methods, procedures and tools described in the literature, it is appropriate to explore, if these methods are used in the specific business environment. For 
this purpose a part of questionnaire survey, described in further detail later, constructed for purposes of the project SP2017/102 Research of Selected Approaches to Risk Treatment in Industrial Companies was analysed. The survey was intended as a pilot research for detection of possible trends in approaches to risk management in a particular region and provided data for the trial classification of approaches to risk management in a sample of companies.

\section{Existing methods for risk management and their classification}

As mentioned before, there is a wide variety of methods applicable in risk analysis and management cited in the literature. About fifty methods and techniques applicable in risk management are mentioned for example by Korecký and Trkovský (2011), Fotr and Hnilica (2014), Kruliš (2011), Procházková (2011), Chapman (2006), Tichý (2006), Popov, Lyon and Hollcroft (2016), some of them can be also found in ISO 31010. The house of risk method is presented by Pujawan and Geraldin (2009). And this is not the overall review of the available methods.

Studying the methods in detail, it can be seen, that they are of a different character. The methods have special requirements on input information, different character of an output and they are designed for different phases of either risk management either production processes as mentioned in related literature as Korecký and Trkovský (2011) or in ISO 31 010. The methods are expected to be included into the framework which is basically outlined in the paper. The realization of the outlined procedures is planned as a part of a further research.

\subsection{Current approaches to classification of methods}

In such amount of the methods and techniques with diverse characteristics and conditions for use it is appropriate to classify the methods for the purposes of their appropriate selection for a particular use in a company environment.

Frequently risks itself are divided into particular groups (for example the classification mentioned by Korecký and Trkovský (2011)). Also many criteria are used for classification of risks as mentioned by Tichý (2006) or Fotr and Hnilica (2014). The methods are also classified, but they are not as frequently categorized as risks itself.

The first view on the classification can be realized based on the step of the risk management process (risk identification, risk analysis/measurement, risk treatment) as mentioned for example by Fotr and Hnilica (2014), Korecký and Trkovský (2011), Tichý (2006). The methods used in risk management can be divided into two groups in relation to used data. These groups are quantitative and qualitative methods as mentioned by Smejkal and Rais (2013). Another type or classification can be based on the subject matter of the analysis as mentioned for example by Kruliš (2011). Pandian (c2007), divides risk identification into generic methods and formal structured methods. Korecký and Trkovský (2011) divides the methods for analysis of risks into these groups: methods for basic description, methods based on statistics and simulations, methods using scenarios and diagrams and methods connected with decision making. This categorisation is realized according to the nature of methods.

Korecký and Trkovský (2011) also focus on the classification of the methods and outline a basic framework for companies to determine which method is appropriate to use. In case of the methods for identification of risks, a matrix assessing methods according to their applicability for projects with different levels (high, medium and low) of two parameters: importance of the project and level of risk in the project is used by Korecký and Trkovský (2011). The matrix can be considered as two-dimensional evaluation of the methods. A method can be also labelled as 
a basic method for particular type of project (with certain risk and importance level) or a supplementary method, so the other perspective is added. Korecký and Trkovský (2011) similarly defines a guideline for companies, simplifying decision making processes by identification which method is suitable to use in which phase of a project realisation. For each method their suitability to be used in the particular phase of the process is assessed as basic, supplementary or only in case of hazard. The methods are additionally evaluated by their importance for risk management (four levels are used: applicable for most of the projects, suitable for more hazardous projects, supplementary use and methods used for hazards assessment).

The classification based on more factors is described in ISO 31010 norm, where three main areas are assessed. These areas are: resources, nature and level of uncertainty and complexity of the methods. Each of these characteristics is assessed by three levels: low, middle and high. In ISO 31010 norm, the fact if outputs from an analysis has quantitative or qualitative character, is also considered. In the norm there are also mentioned factors influencing a decision which method should be used. Likewise as mentioned by Korecký and Trkovský (2011) the categorization or the guideline, in ISO 31010 norm, the methods are evaluated by their applicability in the different phases of management processes. (ČSN ISO 31000, 2011)

A further comparison is realized for example in a field of root cause analysis, where Aurisiccchio, Bracewell and Hooey (2016) mention four factors based on Livingston et al. (2001), Gano (2007), Doggett (2004) and Doggett (2005) and Katsakiori, Sakellaropoulos and Mantakis. (2009). These four factors are: applicability in a particular stage of product development, type of input information, level of structuralization and guidance and whether the method is focused forward in time or on historical data.

\section{Classification of methods - possibilities and the outline of a framework}

Although all existing approaches to classification of methods are not stated in this paper, frequently only one criterion is used to categorize the methods. In ISO 31010 or mentioned by Korecký and Trkovský (2011), the more complex framework for evaluation is described. Many factors influence decision making processes, so more than one dimension can be taken into account, when evaluating the methods according to their applicability. Based on the previously mentioned literature connected to the current approaches to the classification of the methods in the paper and the literature related to risk management as Korecký and Trkovský (2011), Raydugin (2013), a list of factors or dimensions for assessment of the risk management methods is stated here:

- $\quad$ Financial demands
- $\quad$ Sime demands
- $\quad$ Human resources requirements
(number of employees)
- $\quad$ Demands on knowledge
- $\quad$ General use
- $\quad$ Fault resilience
Existence of manuals, consequent
steps

$\begin{array}{ll}\text { - } & \text { Interpretation } \\ \text { - } & \text { Obisualization } \\ \text { - } & \text { Small possibility to overlook risks } \\ \text { - } & \text { Possibility to reuse the analysis } \\ \text { - } & \text { Connection with other risk } \\ \text { - } & \text { Output type } \\ \text { - } & \text { Phase in which the method is used } \\ \text { - } & \text { Historical data or prediction }\end{array}$




\subsection{Cluster analysis as a tool for risk management classification}

If considering such a sum of factors, a basic classification in a form of a matrix or a table would be too complicated. The other complication in the process of evaluation is that for different companies, different characteristics can be more or less useful, so it is complicated to generally evaluate which variants are better or worse. These two requirements might be reasons for use of the clustering which is based on more than one dimension and produces groups of objects (in this case methods) (Everitt 2011). This also removes the problematics of different preferences of different types of companies and the methods are sorted not from the generally best method to the less useful, but according to their characteristic, so companies can choose a method or a group of methods according to their preference.

Clustering is based on dissimilarities (or similarities) of objects in the analysis (for example Hebák et al. 2005). There are several different metrics for a computation of the dissimilarities in case of strictly numerical inputs (variables) (Foster 2017). But in case of assessment of the methods, mixed types of factors can be expected. For the cases, where all data have not the numeric form, procedure formulated by Gower (1971) and mentioned by Kaufman and Rousseeuw (1990) is used. The formula (1) for the calculation of the metric is used as follows

$$
S\left(x_{i}, x_{j}\right)=\frac{\sum_{l=1}^{d} \delta_{i j l} s_{i j l}}{\sum_{l=1}^{d} \delta_{i j l}}
$$

where for data set of d objects $S_{i j l}$ represents the similarity between objects $x_{i}$ and $x_{j}$ for the $1^{\text {th }}$ characteristic (or variable), $\delta_{\mathrm{ijl}}$ is a coefficient with values 0 or 1 depending on if a value is missing. For nominal values $S_{\mathrm{ijl}}$ is 1 if $\mathrm{x}_{\mathrm{il}}=\mathrm{x}_{\mathrm{jl}}$ and 0 if $\mathrm{x}_{\mathrm{il}} \neq \mathrm{x}_{\mathrm{jl}}$. The equation (1) id mentioned for example by Xu and Wunch (2009).

After the computation of the distances between all pairs of the methods according to their characteristics, a clustering algorithm is applied. Clustering can also be realized using various clustering algorithms described by many authors for example by Mirkin (2013) or Řezanková, Húsek and Snášel (2009). For the potential classification of the risk management methods, the average linkage is chosen in combination with the Gower metric.

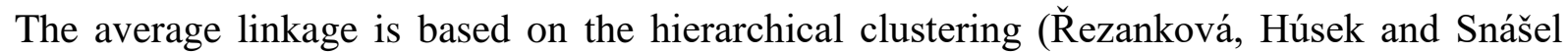
2009). Average distances between two clusters are calculated from distances between all objects (methods or in the case of the questionnaire survey - companies) belonging into two different analysed clusters (Hebák et al. 2005). The process is realized by connecting two single objects (methods or companies) with the smallest distance (Mirkin 2013), (Xu a Wunsch 2009). After the first step of the clustering, where the former clusters labelled as $\mathrm{h}$ and $\mathrm{h}$ ' are connected into the new cluster $\mathrm{g}$, distances between the cluster $\mathrm{g}$ and the other clusters labelled as $\mathrm{g}$ ' must be recalculated. For this purpose the formula (2) is used

$$
\mathrm{D}_{\mathrm{gg}}{ }^{\prime}=\frac{\mathrm{n}_{\mathrm{h}} \mathrm{D}_{\mathrm{g}^{\prime} \mathrm{h}}+\mathrm{n}_{\mathrm{h}^{\prime}} \mathrm{D}_{\mathrm{g}^{\prime} \mathrm{h}^{\prime}}}{\mathrm{n}_{\mathrm{h}}+\mathrm{n}_{\mathrm{h}^{\prime}}}
$$

where $D_{g g}$ represents distance between the cluster $g$ and $g, n_{h}$ is the number of objects belonging to the cluster $\mathrm{h}, \mathrm{n}_{\mathrm{h}}$, is the number of objects in the cluster $\mathrm{h}^{\prime}, \mathrm{D}_{\mathrm{g}^{\prime} \mathrm{h}}$ is the distance between clusters $g^{\prime}$ and $h$, correspondingly $\mathrm{D}_{\mathrm{g}^{\prime}} \mathrm{h}^{\prime}$ is the distance between clusters $\mathrm{g}^{\prime}$ and h'(Hebák et al. 2005). The step of connection of clusters with the smallest distance and recalculation of distances is repeated as mentioned by (Mirkin 2013), (Xu a Wunsch 2009).

A selection of suitable variables, data types (quantitative, qualitative - binary, ordinal or nominal, described for example by Řezanková, Húsek and Snášel (2009)) and appropriate scales for their measuring are beyond the scope of this paper and are considered as subject of 
the further research. Concurrently the identification of consistent groups of risk management methods and their further analysis is considered to be the subjects of the additional research developing the basic thoughts in this paper. The cluster analysis is also applied at results of the questioning which is described in the consequent part of the paper, results of the cluster analysis are displayed in 3.3 Results from the pilot questioning - approaches to risk management.

\section{Analysis of the questionnaire results}

A questioning focused on risk management systems (and methods) was realized as a part of a pilot survey. The pilot survey was compiled from partial questionnaires focused on different, but related, topics. The pilot survey was prepared for purposes of the project SP2017/102 by author and other team members. The partial questionnaire analysed in the paper has been constructed with an intention to examine the use of the methods previously mentioned in this paper and to broaden the view on the problematics by data from practice.

The questionnaire focused on risk management includes five areas, respectively questions, related to risk management approaches. Those questions are displayed in Table 1. The questions were constructed also to reflect knowledge from the literature related to risk management as for example Korecký and Trkovský (2011), Smejkal and Rais (2013), Raydugin (2013), Poppov, Lyon and Hollcroft (2016), Kotler and Caslione (2009) and other literature sources mentioned in the paper. This part of the survey (questioning) included closed questions with the predefined answers, four of them with one possible answer. In question three, more than one method could be chosen and the possibility to write other method than predefined ones has been given to the respondents.

Table 1: Questions related to risk management

\begin{tabular}{|l|}
\hline 1. How often risks or resources of risks (as market trends, situation in business, new technologies) are monitored? \\
\hline 2. Is the risk appetite criterion defined for the company (for main processes)? \\
\hline 3. Choose methods used for risk assessment in the company. \\
\hline 4. Are there any employees responsible for risk management in the company? \\
\hline 5. Are there any tools or warning system informing about forthcoming risks? \\
\hline
\end{tabular}
Source: A part from the survey prepared for purposes of the project SP2017/102 - questionnaire focused on approaches to risk management (translated)

\subsection{Brief description of the respondents}

The companies from various fields in business, with intent to focus on industrial companies, were contacted electronically to fill the questionnaire anonymously. Firstly the companies were contacted via the Regional Chamber of Commerce and also based on the contacts from previous cooperation between the academic and the business spheres.

Fifteen companies finally participated in the survey. Respondents were filling forms and sending the questionnaires electronically from May 2017 to the end of June 2017. Final number of respondents is despite efforts relatively small. It was expected to gain a significant amount of information from companies, which turned out as problematic. Due to the smaller amount of participants, the results from the questionnaire analysis are used only for outlining tendencies or trends in risk management and to detect areas which should be analysed in further detail. The findings can't be used for generalisation and are valid only for the sample of respondents. Nevertheless an attempt to perform a test task was made with regards to the small amount of respondents, so the data can't be taken as statistically significant for the purposes of generalisation. In spite of these facts the data from companies were used for purposes of verification of particular methods or approaches and to identify possible starting questions for the further research. 
If the size of the companies is taken into account, the participating companies were divided into two groups: large companies with a number of employees bigger than 249 (this criterion is also mentioned by Smallbone (c2010)) and middle and small companies (40\% of companies in the survey can be considered as middle and small companies). The final structure of the respondents based on the field of their business includes $33.33 \%$ of machinery and automotive companies, $20 \%$ of companies from food, pharmaceutical and chemical industry, one company from the category of energy and water industry and $40 \%$ of companies which are not belonging to defined categories.

The companies with a longer tradition are included in the survey and only one company is in 6 - 10 years period of existence on the market, $33 \%$ of the companies belong to $11-20$ years span, 26,67 \% belong to the group lasting $21-30$ years on the market and $33 \%$ has the history longer than 31 years. $60 \%$ of the companies are owned by Czech owners fully or with major shares. Products or services produced by companies are from $53 \%$ B2B products or services and from $47 \% \mathrm{~B} 2 \mathrm{C}$ products or services.

\subsection{Results from the pilot questioning - basic findings}

Despite the fact that outcomes from the questioning are not suitable for generalisation due to the smaller amount of the respondents, results from the questionnaire are taken as supplementary to the overview and proposed framework for methods' assessment or classification and are used to identify possible areas for the further research and trends in risk management.

Focusing on the first question, there was found out, that the companies in the questioned sample do not underestimate the importance of monitoring of risks. Over $60 \%$ of the companies are monitoring risks continually. In contrast, there weren't any companies with no monitoring of risks. The results are presented in the Figure 1. There were no significant differences in structure of the answers found if the size of the companies is considered.

Figure 1: Frequency of monitoring the risks in companies

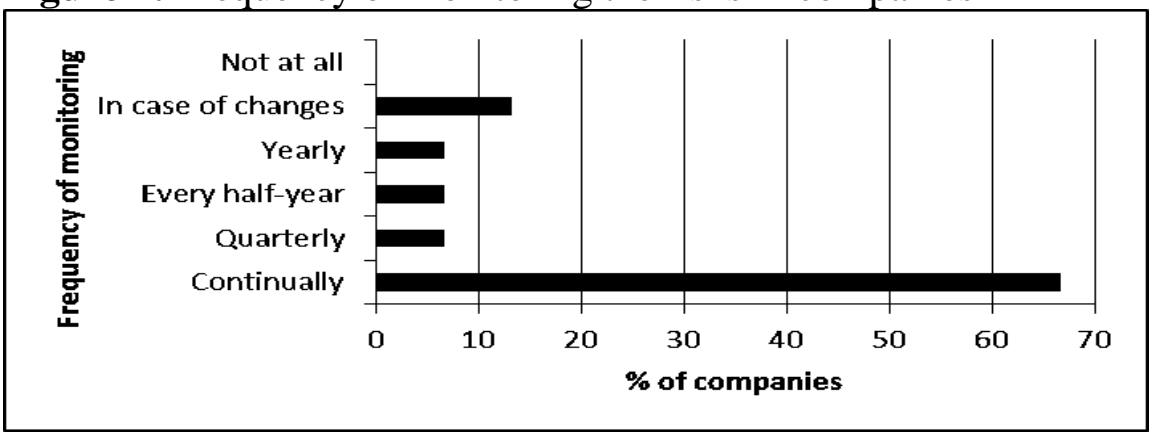

Source: Author's processing based on the questionnaire outputs.

Although the companies pay attention to the risk monitoring, a risk appetite criterion isn't defined in $40 \%$ of cases as it can be seen in the Figure 2. Unexpectedly, in the large companies more cases of missing risk appetite criterion appeared (absolutely and also relatively). The least frequent answer was the criterion defined only for processes.

If this result is contrasted with the previous conclusions, this leads to a noteworthy deduction, that even though some of the companies concentrate on monitoring, they lack tools for detection of intolerable threads. The question, if the missing border for acceptability could lessen effectiveness of risk management as the certain moment for treatment application on the risk is not specified, appears. 
Figure 2: Risk appetite criterion

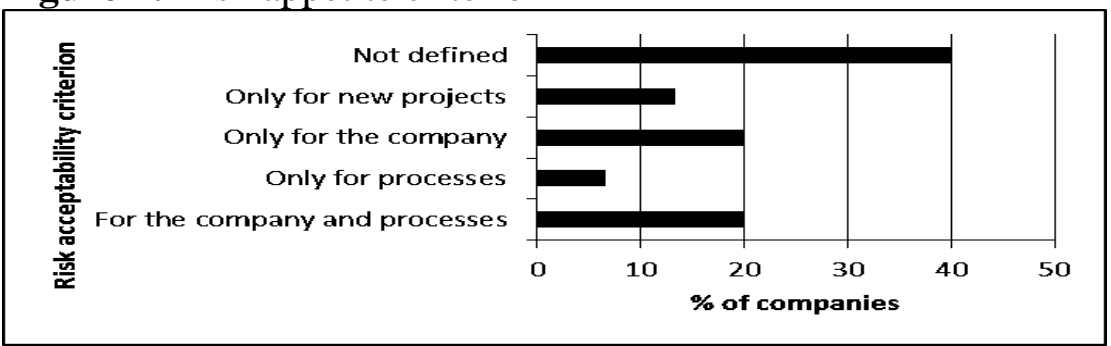

Source: Author's processing based on the questionnaire outputs

The other area on which the questionnaire was focused is which methods are used for risk management in the companies. There was the possibility of multiple answers in this question, so $\%$ of companies using a method to overall number of companies was calculated. The mostly used method are discussions (about $53 \%$ of companies), even in the large companies. Lists of risks are also frequently used, mainly in the large companies. Cause and effect diagrams and scenarios are used each in approximately $33 \%$ of the companies participating in the questioning. The method, which is used the least, is a probability-consequence matrix. Also a category "others" appeared with an answer which is, that the company uses own opinions for risk management. Discussions and lists of risks are used more in big companies whereas scenarios and expert evaluation is used more in small and middle companies.

Almost every company taking part in the questioning uses at least one of the mentioned methods (except of one company). In average a company uses two methods for risk management. From this, it can be derived that risks are also handled methodically, not only intuitively. In the sample of companies a variety of the methods for work with risks is indicated. The results related to the third question are displayed in the Figure 3.

Figure 3: Particular methods used in companies

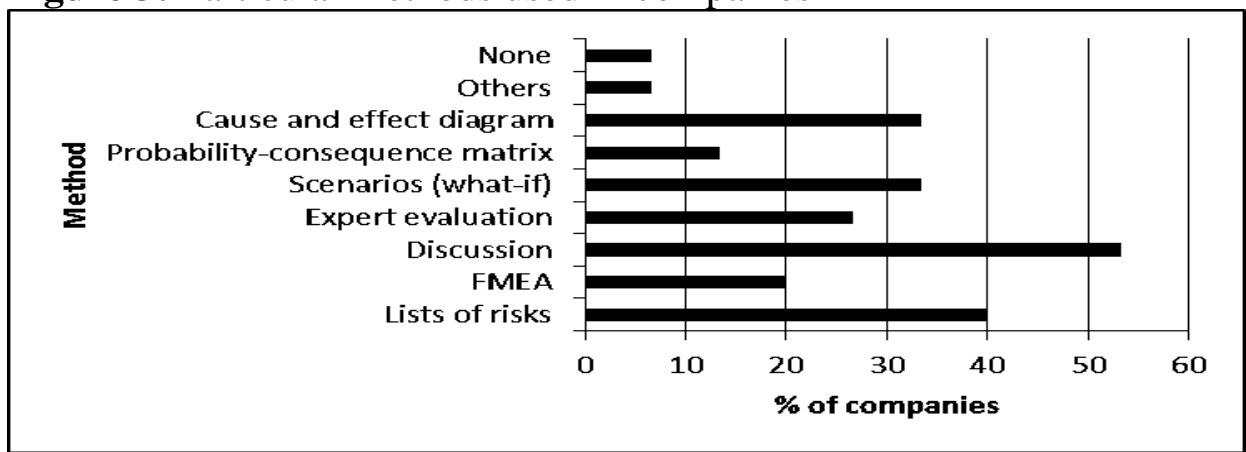

Source: Author's processing based on the questionnaire outputs.

The important step in risk management is to define responsibilities (as mention for example Korecký and Trkovský (2011) or ISO 31000 ) and organisational structures (described for example by Smejkal and Rais (2013)). The relatively big amount of the companies participating in the questioning (about $26 \%$ ) has no specific person responsible for risk management. The most frequent answer was process guarantors and (or) leaders of departments as the employees accountable for that area, as it can be seen in Figure 4. Exactly $40 \%$ of the questioned companies apply that model. The responsible persons are also top management members.

None of the companies in the research sample has leaders of risk management groups. From the results of the sample group of large companies, the trend of a decentralised concept of risk management can be identified. This approach has an advantage of good knowledge of a 
situation in a particular department, but also generates a risk of a low interconnection between single groups or employees responsible for risk management, these opinions are derived from the general advantages and disadvantages of organizational structures (for example Smejkal and Rais (2013).

Figure 4: Employees responsible for risk management

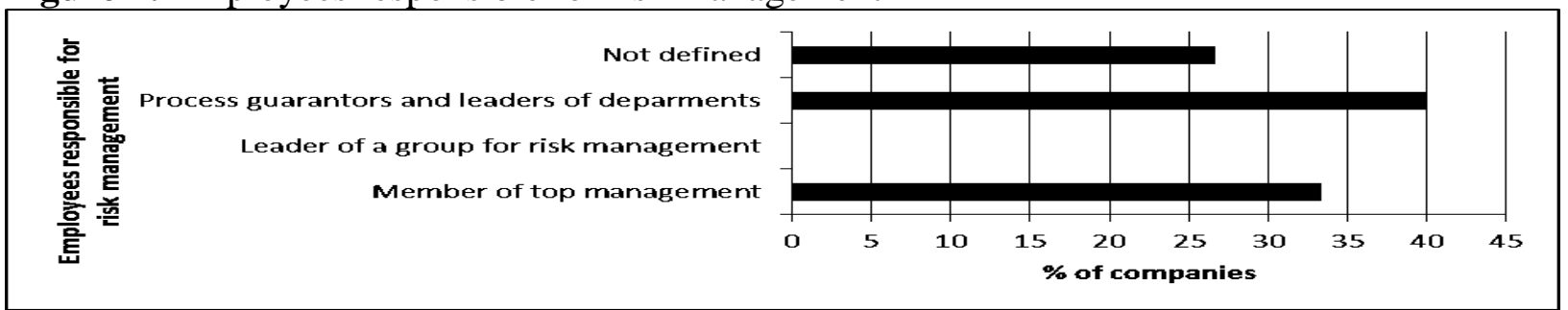

Source: Author's processing based on the questionnaire outputs

When dealing with risks, the early detection has its importance. The problematics of risk detection is mentioned for example by (Kotler and Caslione 2009). Although the application of principles of warning systems can improve work with risks (Kotler and Caslione 2009), $33 \%$ of the companies do not use such systems as displayed in Figure 5. Own systems interconnected with risk management system are used by $20 \%$ of the companies. External solution from a specialized company and signals from particular company agendas are not used by any company from the sample. The companies use the signals from various subjects: signals from mother-companies (about $13 \%$ ), from cooperating companies (about $6 \%$ ) and signals form employees which are in contact with subjects from external business environment. Approximately $13 \%$ of the companies use some aspects of early detection warning system.

Figure 5: Early detection warning systems

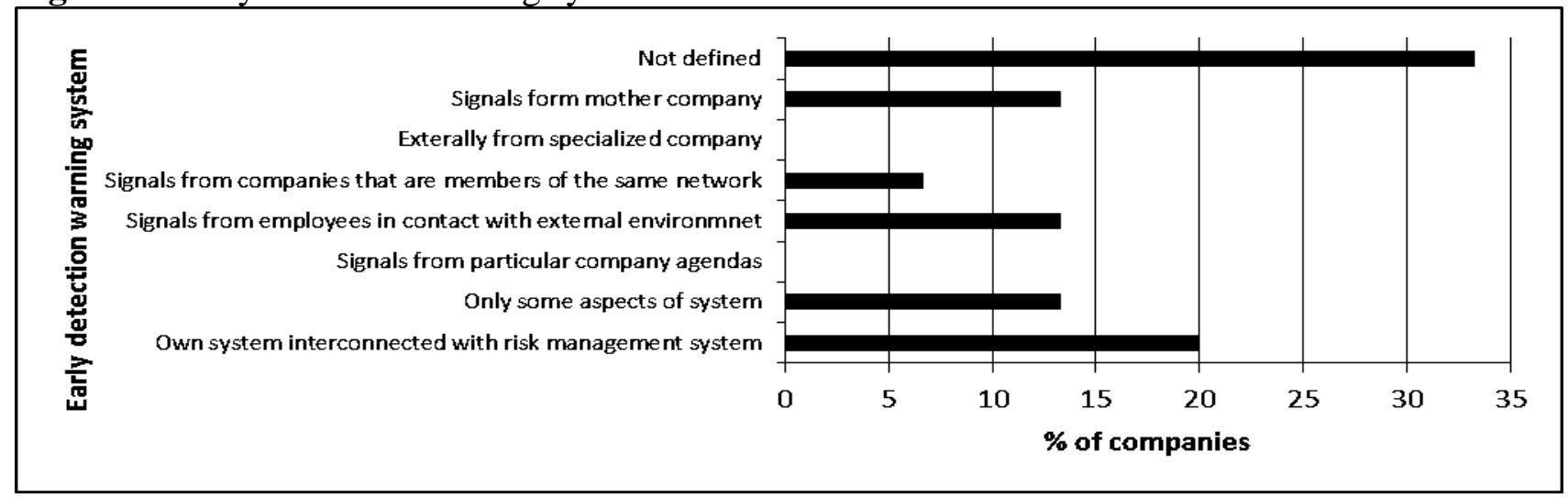

Source: Author's interpretation based on questionnaire outputs.

\subsection{Results from the pilot questioning - approaches to risk management}

Several ways of work with risks or approaches to risk management can be used (applied) in companies. Methodologies can vary from a company with highly developed risk management systems to a company using almost no risk management. Although many styles in risk management can be used, it could be meaningful to define the specific approaches or groups of companies threating risk correspondingly. The companies are compared according to more than one parameter to find similar approaches to work with risks to identify signals indicating analogical attitude to management. Because of the small amount of respondents, the results are valid for this group of companies. 
Firstly the companies are, in this paper, assessed using a simple method as description based on two selected factors which generally have a form of a scale. The classification is usually based on a matrix, where each factor is represented by one of the axes. Methodology of the matrix creation is mentioned for example by Korecký and Trkovský (2011). In the view of the amount of respondents, matrices are not constructed here in the paper (but hey would have its relevance in case of a larger sample of respondents) but the most significant findings valid for the available sample are presented in the paper expressed as percentages of the companies with a particular combination of factors.

Two combinations of scales were used - frequency of monitoring risks vs. risk appetite (acceptability) criterion and early warning systems vs. risk appetite criterion. The scales are defined as can be seen in Fig. 1, Fig. 2 and Fig. 3 as the variants of responses correspond with the scales. The scales (based on the questioning) were also inspired by different methodologies and approaches to risk management mentioned for example by Korecký and Trkovský (2011), Raydugin (2013), Poppov, Lyon and Hollcroft (2016) and Kotler and Caslione (2009) - in relation with early warning systems.

If the combination of frequency of monitoring and the existence of a risk appetite criterion is considered, the most numerous group of companies is the group which is monitoring risks continually, but without defined risk borders (33.33\% of all respondents). Companies with continual monitoring and a determined criterion for the processes and also for a company represent $13.33 \%$ of the respondents.

Similarly, companies from a view of a risk appetite criterion and an early warning system existence are compared. It can be seen, that $20 \%$ of the companies have the higher level of interconnection between an early warning system and an assessment of risks from the view of acceptability (combinations of existence of the criterion for a company and for processes and own early warning systems (13.33\%) or at least with some aspects of own early warning system. Conversely $26.67 \%$ of the questioned companies have neither an early warning system, nor a risk appetite/acceptability criterion.

The approaches to risk management can be taken as a more complex subject and can include more than two factors. For the creation of the groups concerning more factors or dimensions, the cluster analysis is used. The clustering was realized based on the Gower metric and the average linkage described in the section 2.1 Cluster analysis as a tool for risk management classification. The clustering is based on smaller number of companies, so the results have a character of trend identification and also verification of the usability of the cluster analysis for purposes of risk management. Outcomes from the analysis describe only the respondents of the questionnaire.

Based on the responses from the companies, six factors are defined. One quantitative discreet variable (number of methods, taken as ordinal variable for the purposes of the assessment), three nominal (types of methods, responsible employees and early warning systems) and two ordinal variables were used in the analysis (frequency of risk monitoring - continually is the best option and risk appetite criterion - the best option is a criterion for the processes and a company as a whole).

The variable "type of the used methods" can be divided into structuralised and intuitive based on two groups of methods for risk identification mentioned by Pandian (c2007). In this case the classification was only inspired by these two categories mentioned by Pandian (c2007) and is 
generalised for all methods (not only the methods for risk identification). Methods are divided into category with a firm structure (check lists, cause and effect, probability-consequence matrix and FMEA) and methods with less strict structure (discussions, expert evaluation and scenarios). If only structuralised methods are used in a company, for this factor it is labelled as "structuralised". In case of only intuitive methods with less strict structure, particular company is labelled as "non-structuralised" for factor "type of used methods". If both types of methods are used in a company, value of "type of used methods" is "mixed". In case of no used method, the label is "none". In case of scenarios (or what-if analysis), this term can include either structuralised or non-structuralised methods (Fotr and Hnilica 2014 and also Korecký and Trkovský 2011 - they mention structuralised what-if analysis, Smejkal and Rais 2013, Korecký and Trkovský 2011, Tichý 2006 mention scenarios as the non-structuralised approach). Due to the dual character of scenarios, also version with "structuralised" scenarios is analysed.

Concerning these factors a hierarchy of the companies' approaches to risk management is created as displayed in the Figure 6. This form of presentation of the results from the cluster analysis is mentioned for example by Xu a Wunsch (2009). For the further description, four groups (or clusters) of companies with the similar approach to risk management are defined. The questioning was anonymous, so the companies are labelled by the numbers.

Figure 6: Hierarchy of approaches of the companies to risk management

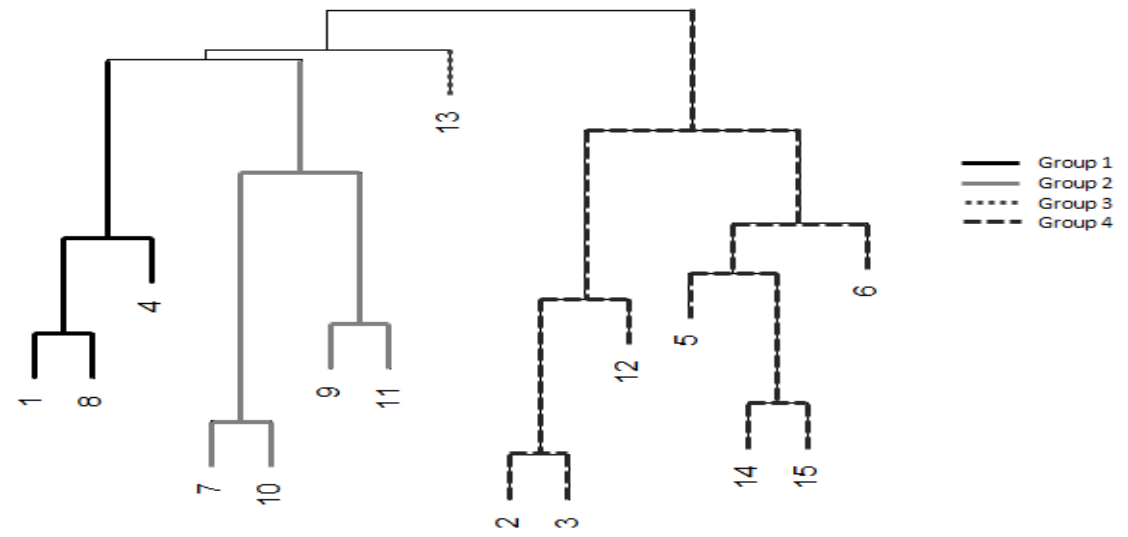

Source: Author's processing and analysis based on questionnaire outputs using R program - Maechler, M., Rousseeuw, P., Struyf, A., Hubert, M., Hornik, K (2016), R Core Team (2017)

The defined groups of the companies can be described by their common characteristics. The first group including three companies (1,8 and 4) could be described as focused only on partial aspects of risk management, specifically on the monitoring of risks. Conversely, the risk appetite criterion is not widely used. Risk management is included in general managerial processes at top-management level. The companies in this group use in average slightly lower amount of the methods for risk management (than the overall average which is about 2 methods). Mostly, some aspects of the early detection or warning systems are applied in this group. Companies in this group have the longer history on the market and ownership of Czech owners in common.

The second group (companies 7, 10,9 and 11) is at the highest level from all described groups considering risk management. There are risks monitored frequently in this group of companies and also the criterions for their evaluation are mostly set. This group is characterised, in general, by using a big amount of methods (in average 4 methods in a company), structuralised and nonstructuralised, for risk management. The different approach compared to the first group is identified in the field of responsible employees. Decentralization is used there, when guarantors 
of processes are the responsible persons. In this group 3 of the companies has history longer than 31 years in the market and the remaining one is in 11-20 years. Also the companies owned $100 \%$ by foreign owners are dominating (3) and the remaining company has fully Czech ownership. Correspondingly with this fact, three companies are in the group of big companies.

In the third group, only one company is included (number 13). This company has the specific approach to risk management compared to the others. This company is not much concentrated on monitoring of risks, but applies assessment of risks from the view of the acceptability. The structuralised methods for risk management are used there and the company applies some aspects of the early warning system. Top managers are the responsible persons for risk management.

The last group is not generally much concentrated on risk management, however the approaches in this group slightly differs. In general, the companies are not focused on the use of the risk appetite criterion. The companies in this group use both types of the methods, structuralised and also non-structuralised. One company also uses method which is not defined in the questionnaire (risk management based on own judgements) and one uses no method. The focus on the early detection of forthcoming risks and also clearly defined employees responsible for risk management is relatively lower. If the approaches to responsibilities of employees are described, the companies in this group have no responsible employees in the field of risk management or the process guarantors/department leaders are persons, who are accountable for risk management processes. The companies use smaller amount of methods for risk management than in the second group. If frequency of risk monitoring is described, two different approaches can be identified. In the companies 2, 3, 5, 12 risks are monitored continuously. In the other companies, focus on risk monitoring is not that strong. If the subgroup, including companies 2, 3 and 12, is described, in this group (in average) fewer methods are used and these methods are not structuralised. Companies 2, 3 and 12 have (in average) shorter tradition on the market.

If the scenarios are considered as structuralised, changes in the results of the cluster analysis appears due to quite frequent use of the scenarios according to the questionnaire. Three main groups are identified: The first group (including companies - 1, 2, 3, 12, 5, 14, 15) is similar to the fourth group formed in previous analysis, also characteristics are similar, the second group consists of companies with numbers $6,9,11$ - they are generally focused on monitoring, more focused on acceptability criterion than the first group, use more methods for risk management. Responsible persons in risk management are the guarantors/department leaders and companies in this group are less focused on early warning systems. The third group (companies 4, 7, 8, 10, 13) compared to the first and the second group is generally more focused on acceptability criterion and early warning systems and also top management members are responsible for risk management. Except of responsible persons, in this group some similarities (in average) to the second group (Fig. 8) can be identified.

\section{Conclusion}

Risks which are threatening subjects in business environment can be handled by many tools, procedures and methods for risk management. Some of them are listed in the literature, for example Korecký and Trkovský (2011), Fotr and Hnilica (2014), Kruliš (2011), Procházková (2011), Chapman (2006), Tichý (2006), Popov, Lyon and Hollcroft (2016), some of them can be also found in ISO 31010. These methods have different characteristics, requirements and are suitable to use in different steps of management processes as characterised in the related literature. 
This diversity of the methods leads to requirements to classify them. As risks are classified, also the tools and methods for their management are categorized. In this paper, some of the categorization criterions mentioned by several authors were presented. Frequently, the categorization is based on one criterion, but also more complex methodologies, considering several dimensions of the assessment of the methods, are described by authors of the risk management related literature. In this paper, the elementary outline of the possibly applicable procedure was described there. This classification is intended to include more dimensions or characteristics of the methods and also to create groups of the comparable methods rather than find the best and the worst method globally for all circumstances. Classification itself is expected to be the subject of the further research.

The last part of the paper includes the complementary results of a pilot questioning that is intended as a pre-research to identify trends or possible hypotheses for the further research. This questioning is based on the electronic questionnaire. The questionnaire that is one section of the pilot survey constructed for purposes of the project SP2017/102 Research of Selected Approaches to Risk Treatment in Industrial Companies was used.

Within the analysed companies, tendencies to the continual or frequent monitoring of risks were identified. On the contrary the specific criterions for the specification which risks are inacceptable are used less frequently (40\% of the questioned companies don't use the acceptability criterions). Based on the respondents' answers, it can't be stated, that big companies use risk appetite/acceptability criterion more than small companies (ratio of the companies with no defined criterion was even bigger in the group of big companies). Early warning systems also aren't that common among the companies, but the ratio of companies with no early warning system is not bigger among the small and middle companies. At least one method for risk management is used almost in every companies participating in the questioning (only one company answered, that they use no methods within option "others"). In average, a company uses about two methods for risk management. Big companies use structuralised and also non-structuralised methods as well as small and middle companies. In big companies discussions and risk lists are prevailing whereas in small/middle companies scenarios and expert evaluations are used.

The trial classification of the approaches to risk management was also realised based on the questioning. Two combinations of factors and one clustering procedure were created. Based on the basic two-factor approach, it can be stated that significant number of the questioned companies are concentrated on the monitoring but there is missing a criterion to evaluate the acceptability of a potential risk (33\%). This result is valid only for the respondents, but this outcome can be taken as a potential object for further studies. From more than $26 \%$, companies taking part in the questioning have no early warning system in combination with no criterion to assess potentially identified threads. In the further research a focus can be on the question, whether the combination of no early warning system and no criterion is only isolated phenomenon specific for this group of companies or if it occurs among a larger scope.

Based on the cluster analysis, four approaches were identified (three main groups and one group including the company with the specific approach). Despite the fact that the analysis has a character of the test task applied on the small range of companies it is possible to identify similarities in risk management approaches. One group of companies that can be labelled as concentrated on risk management, one group of companies with mixed approach (these companies are focusing on partial aspects of risk management as risk monitoring), companies less focused on risk management and one company with the specific approach - focused on 
criterions for risk management and partially early warning system without emphasis on the monitoring. The group with the best results from risk management point of view consists of companies established on the market and mainly owned by foreign owners. Approaches identified base on the sample of companies. A question for further research and for verification of the results in case of larger sample of the companies arises from the identification of the approaches to risk management.

\section{Acknowledgement}

This article was created with the support ${ }^{1}$ of specific research project SP2017/102 - Research of Selected Approaches to Risk Treatment in Industrial Companies ${ }^{2}$.

\section{References}

[1] AURISICCHIO, M., R. BRACEWELL and B. L. HOOEY, 2016. Rationale mapping and functional modelling enhanced root cause analysis. Safety Science (85). Elsevier. p. 241 - 257. ISSN $0925-7535$.

[2] ČSN EN 31010, 2011. Management rizik - Techniky posuzování rizik. Praha: Úřad pro technologickou normalizaci, Metrologii a státni zkušebnictví. 80 p. Tř́ídící znak 010352.

[3] DOGGETT, A. M., 2004. A statistical comparison of three root cause analysis tools. J. Indust. Technol. 20 (2), p. 1 - 9.

[4] DOGGETT, A. M., 2005. Root cause analysis: a framework for tool selection. The Quality Manage Journal. 12 (4), p. 34 - 35. ISSN: 1068-6967

[5] EVERITT, B., 2011. Cluster analysis. 5th ed. Chichester, West Sussex, U.K.: Wiley. Wiley series in probability and statistics. ISBN 0470978449.

[6] CHAPMAN, R. J., 2006. Simple tools and techniques for enterprise risk management. Chichester: Wiley, xxiv, 466 p. ISBN 0-470-01466-0.

[7] FOSTER, I. et al., 2017. Big data and social science: a practical guide to methods and tools. Boca Raton, FL: CRC Press Taylor \& Francis Group. ISBN 9781498751407.

[8] FOTR, J. et al., 2012. Tvorba strategie a strategické plánování: teorie a praxe. 1. vyd. Praha: Grada Publishing, 381 s. ISBN 978-80-247-3985-4.

[9] FOTR, J. and J. HNILICA, 2014. Aplikovaná analýza rizika ve finančním managementu a investičním rozhodování. 2. aktualiz. a rozš. vyd. Praha: Grada Publishing. 304 s. ISBN 978-80-247-5104-7.

[10] GANO, D. L., 2007. Apollo Root Cause Analysis - A New Way of Thinking. Third ed. Apollonian Publications LLC.

[11] GOWER, J. C., 1971. A general coefficient of similarity and some of its properties, Biometrics 27, 857-874. 0006-341X

[12] HEBÁK, P. et al., 2005. Vicerozměrné statistické metody. (3). Praha: Informatorium. 255 s. ISBN 80-7333-039-3.

[13] KATSAKIORI, P., G. SAKELLAROPOULOS and E. MANTAKIS, 2009. Towards an evaluation of accident investigation methods in terms of their alignment with accident causation models. Elsevier. Safety Science 47 (7). p. 1007 - 1015. ISSN 0925 - 7535.

\footnotetext{
${ }^{1}$ SGS EKF, VŠB-TU Ostrava

${ }^{2}$ translated from the original: “Zkoumání vybraných postupů pro práci s riziky v průmyslových podnicích"
} 
[14] KAUFMAN, L. and P. J. ROUSSEEUW, 1990. Finding Groups in Data: An Introduction to Cluster Analysis. Wiley, New York. ISBN: 9780471878766

[15] KOTLER, P. and J. A. CASLIONE, 2009. Chaotics: the business of managing and marketing in the age of turbulence. New York: Amacom, 224 p. ISBN 978-0-8144-15210 .

[16] KORECKÝ, M. and V. TRKOVSKÝ, 2011. Management rizik projektů: se zaměrením na projekty v prümyslových podnicích. 1. vyd. Praha: Grada Publishing. 584 p. ISBN 978-80247-3221-3.

[17] KRULIŠ, J., 2011. Jak vítězit nad riziky: aktivní management rizik - nástroj ř́zení úspěšných firem. Praha: Linde, 2011, 568 p. ISBN 978-80-7201-835-2.

[18] LIVINGSTON, A. D., G. JACKSON and K. PRIESTLEY, 2001. Root Cause analysis: Literature review. Contract Research Report 325/2001 Prepared by WS Atkins Consultants Ltd for the Health and Safety Executive. HSE Books, 62.

[19] MAECHLER, M., P. ROUSSEEUW, A. STRUYF, M. HUBERT and K. HORNIK, 2016. cluster: Cluster Analysis Basics and Extensions. R package version 2.0.5.

[20] MIRKIN, B., 2013. Clustering a data recovery approach. 2nd ed. Boca Raton: CRC Press. ISBN 9781439838426.

[21] R Core Team, 2017. R: A language and environment for statistical computing. R Foundation for Statistical Computing, Vienna, Austria. Accessible from: https://www.Rproject.org/.

[22] ŘEZANKOVÁ, H., D. HÚSEK a V. SNÁŠEL, 2009. Shluková analýza dat. 2. rožs. vyd. Praha: Professional Publishing. 218 p. ISBN 978-80-86946-81-8.

[23] PANDIAN, C. R., c2007. Applied software risk management: a guide for software project managers. Boca Raton: Auerbach/Taylor\&Francis. ISBN 0849305241.

[24] POPOV, G., B. K. LYON and B. HOLLCROFT, 2016. Risk assessment: a practical guide to assessing operational risks. Hoboken, New Jersey: Wiley. ISBN 9781118911044.

[25] PROCHÁZKOVÁ, D. Analýza a řízení rizik. Praha: České vysoké učení technické v Praze, 2011, 405 s. ISBN 978-80-01-04841-2.

[26] PUJAWAN, I. N. and L. H. GERALDIN, 2009. House of risk: a model for proactive supply chain risk management. Business Process management Journal (Vol. 15, No. 6), Emerald Group Publishing, p. 953 - 967. ISSN 1463-7154.

[27] RAYDUGIN, Y., 2013. Project risk management: essential methods for project teams and decision makers. Hoboken: Wiley. ISBN 978-1-118-48243-8.

[28] SMALLBONE, D., c2010. The theory and practice of entrepreneurship: frontiers in European entrepreneurship research. Northampton, Mass.: Edward Elgar. ISBN 9781849803793.

[29] SMEJKAL, V. a K. RAIS, 2013. Rízení rizik ve firmách a jiných organizacích. 4. aktualiz. a rožs. vyd. Praha: Grada Publishing. 488 p. 978-80-247-4644-9.

[30] TICHÝ, M., 2006. Ovládání rizika: analýza a management. Vyd. 1. V Praze: C.H. Beck, xxvi, 396 s. ISBN 80-7179-415-5.

[31] XU, R. and D. C. WUNSCH, c2009. Clustering. Piscataway, NJ: IEEE Press. IEEE series on computational intelligence. ISBN 9780470276808. 